\title{
Positive and negative perfectionism of EFL and non-EFL major graduate students
}

\author{
Mahdieh Noori, Elaheh Sotoudehnama \\ Department of English Language and Literature, Faculty of Literature, Languages and History, Alzahra \\ University, Tehran, Iran.
}

(Received on May 29, 2017; Accepted on March 19, 2018)

\begin{abstract}
Perfectionism as a multidimensional personality construct is not a deeply explored land since accumulated evidence has mainly focused on negative perfectionism while very few studies have investigated positive perfectionism worldwide and particularly in Iran. Overall, not only has no comparison been made between general perfectionism of English as a Foreign Language (EFL) majors vs. non-EFL majors but also no study has yet investigated the Iranian graduate students' perfectionism. To fill these gaps, this study compared the positive and negative perfectionism of EFL and non-EFL major graduate students and investigated whether there is any possible relationship between the participants' major and positive and negative perfectionism development. To these aims, 73 graduate students (26 History and Philosophy of Education and 47 Teaching English as a Foreign Language (TEFL) students) from two Iranian state universities completed the 40-item Positive and Negative Perfectionism Scale (PANPS) of Terry-short, Owens, Slade, \& Dewey (1995). The results of the independent samples t-test revealed that while both groups suffered from a slight degree of negative perfectionism, they equally benefited from high levels of positive perfectionism. These results may implicate strengthening the literature findings that positive perfectionism is corroborated during the Iranian early childhood bearing practices or the household child-parent interactions through the emphasis on the concepts of the best, flawlessness, orderliness, and positive striving. Moreover, they lend credence to the fact that the later-coming variables of academic major or EFL learning act have no considerable impact on the development of perfectionist attitudes.
\end{abstract}

Keywords: EFL Learners, Graduate Students, Negative Perfectionism, Non-EFL Learners, and Positive Perfectionism.

\section{Perfeccionismo positivo y negativo de los estudiantes de Posgrado en Enseñanza del Inglés como Lengua Extranjera (EILE) y no-EILE}

RESUMEN: El perfeccionismo como una construcción de personalidad multidimensional no es una tierra profundamente explorada, A pesar de que la evidencia acumulada se ha centrado principalmente en el perfeccionismo negativo, pero muy pocos estudios han investigado el perfeccionismo positivo en todo el mundo y particularmente en Irán. En general, no sólo se ha hecho ninguna comparación entre el perfeccionismo general de los estudiantes de posgrado en Enseñanza del Inglés como Lengua Extranjera (EILE) y el de no-EILE, sino también ningún estudio ha investigado el perfeccionismo de 
los estudiantes de posgrado iraníes. Para llenar el hueco de conocimiento que existe, este estudio comparó el perfeccionismo positivo y negativo de los estudiantes de posgrado en Enseñanza del Inglés como Lengua Extranjera (EILE) y no-EILE e investigó si hay alguna relación posible entre la educación de posgrado y el desarrollo de perfeccionismo positivo y negativo. Para alcanzar estos objetivos, 73 estudiantes de postgrado (26 de Filosofía e Historia de la Educación y 47 de Enseñanza de Inglés como Lengua Extranjera) de dos universidades públicas iraníes completaron la Escala de Perfeccionismo Positivo y Negativo de 40 ítems de Terry-short, Owens, Slade, \& Dewey (1995). Los resultados de la prueba t para muestras independientes revelaron que mientras ambos grupos sufrían de un ligero grado de perfeccionismo negativo, se beneficiaron igualmente de altos niveles de perfeccionismo positivo. Estos resultados pueden implicar el fortalecimiento de los hallazgos de la literatura que corroboran el perfeccionismo positivo durante las prácticas iraníes de la primera infancia o las interacciones padres-niño a través del énfasis en los conceptos de lo mejor, la perfección, el orden y el esfuerzo positivo. Por otra parte, dan crédito a esta realidad que las variables que vienen más adelante como los estudios de posgrado o Maestría en Enseñanza de Inglés como Lengua Extranjera no tienen un impacto considerable en el desarrollo de actitudes perfeccionistas.

Palabras Clave: los estudiantes de Enseñanza del Inglés como Lengua Extranjera, los estudiantes de posgrado, Perfeccionismo Negativo, los estudiantes de otros posgrados, excepto de Enseñanza del Inglés como Lengua Extranjera, el perfecciomismo positivo.

Correspondencia: Mahdieh Noori, PhD candidate of TEFL, Department of English Language and Literature, Faculty of Literature, Languages and History, Alzahra University, Tehran, Iran. Postal Code: 1993891176. Telephone: 009821 88041461. Fax: 009821 88048038. Email: m.noori@alzahra.ac.ir.

Elaheh Sotoudehnama, full professor in TEFL, Department of English Language and Literature, Faculty of Literature, Languages and History, Alzahra University, Tehran, Iran. Email: esotoude@alzahra.ac.ir.

\section{Introduction}

Perfectionism as one of the major psychological diagnostic criteria is still not a fully explored land since not an agreed-upon definition has been proposed for it yet (Frost, Marten, Lahart, \& Rosenblate, 1990). Put simply, it refers to a set of self-devastating thoughts and behaviors, which are related to reaching excessive high, flawless, and unrealistic goals (Ram, 2005) and a person's attempt for reaching high performance standards that are associated with excessive self-criticisms and concern about others' evaluations (Suddarth \& Slaney, 2001).

Since many individuals are concerned with meeting high performance standards, the perfectionism concept has been studied increasingly in the last few decades (Ram, 2005), developing from a one-dimensional view of perfectionism, which was consistently related with maladjustment (Flett \& Hewitt, 2002; Silverman, 2005), setting and striving for unrealistic standards (Stumpf \& Parker, 2000), failure focus, all-or-nothing way of thinking, and avoidance of self-esteem feelings (Flett, Hewitt, Oliver, \& Macdonald, 2002). More importantly, it was believed that perfectionism was accompanied by negative outcomes of depression (Flett, Hewitt, Blankstein, \& Gray, 1998), doubting behaviors (Slaney, Rice, \& Ashby, 2002), neuroticism (Hewitt, Flett, \& Blankstein, 1991), procrastination, irrational beliefs, feelings of shame (Stumpf \& Parker, 2000), and anxiety (Frost \& DiBartolo, 2002). 
However, recent studies conducted on the different dimensions of perfectionism in the early 1990 s, suggest a multidimensional view of perfectionism with the additive inclusion of adaptive positive, and healthy aspects of perfectionism such as setting high personal standards and organization besides to the previously recognized maladaptive emotional and behavioral components (Chang, Ivezaj, Downey, Kashima, \& Morady, 2008).

Regarding the dimensions of perfectionism, Frost et al. (1990) recognized the five dimensions of concern over mistakes (i.e., to interpret them as failure); personal standards; parental expectations (i.e., the extent to which parental expectations are perceived as setting high standards); parental criticism (i.e., the extent to which parents are perceived as being extremely critical); and doubts about actions (i.e., to doubt one's quality of performance). A further dimension was identified as organization, which is the tendency to be organized and orderly (Alden, Ryder, \& Mellings, 2002; Frost, Turcotte, Heimberg, Mattia, Holt, \& Hope, 1995).

In another dimension, Flett and Hewitt (2002) categorized three dimensions of perfectionism namely, self-oriented, other-oriented, and socially prescribed perfectionism. While the former refers to the unrealistic self-conceptualizations and self-standards, focus on flaws, over criticism, and failure avoidance, other-oriented perfectionism refers to unrealistic expectations and evaluations of other's performance. Socially prescribed perfectionism refers to the assumption that others have high expectations and standards for one's performance (Blankstein \& Winkworth, 2004; Kobori, Yamagata, \& Kijima, 2005).

Another categorization by Hamachek (1978), Rice, Ashby, and Slaney (1998), or Terry-Short et al. (1995) differentiates between adaptive, positive, and healthy versus maladaptive, negative, or neurotic perfectionism, which was based on the idea that setting high performance standards for oneself may be either positive or negative (Campbell \& Di Paula, 2002; Flett \& Hewitt, 2002; Slaney, Rice, \& Ashby, 2002).

Positive perfectionism, which was first claimed by Hamachek (1978), was defined accordingly as the attempt to regulate perfectionism to set and appraise high and realistic personal standards and goal strivings, from the achievement of which pleasant values of success, self-esteem, and selfsatisfaction are gained (Accordino, Accordino, \& Slaney, 2000; Blackburn, 2003; Ram, 2005). This achievement self-satisfaction then contributes to enhance one's satisfactory academic achievements, adaptive learning, coping, and problem solving strategies (Burns \& Fedewa, 2005), higher motivation, lower depression levels, lower anxiety, less stress, and positive personality traits such as self-assurance and assertiveness (Blankstein \& Dunkley, 2002; Ram, 2005). In addition, high self-efficacy, perceived control, goal commitment (Stober, 1998), and optimistic appraisals of minor performance flaws as non-failures (Flett \& Hewitt, 2002; Parker \& Adkins, 1995) are characteristics of positive perfectionism.

On the other hand, Hamachek (1978) described negative perfectionism as an individual's attempt to achieve excessive high and unrealistic goals while he is irrationally appraising his behavior (Frost et al., 1990). These individuals suffer from a continuous fear of failure, academic procrastinations, lack of self-esteem, anxiety, poor coping strategies and academic achievement, higher depression (Ram, 2005), and dissatisfaction and fear of failure in the case 
of facing ignorable flaws in meeting the standards, which ignite them to reach further selfdefeating higher standards (Blackburn, 2003; Frost et al. 1990).

Considering the above-mentioned facts, one may note that according to Parker (2002), negative and positive perfectionism are different personality traits but not separate completely identifiable poles along a continuum.

\section{Review of the related literature}

As already mentioned earlier, the previous studies on perfectionism have mainly focused on one-dimensional maladaptive perfectionism; however, subsequent studies have focused more on the multidimensionality of this construct. The following literature review attempts to reveal the results of the studies on perfectionism at different contexts in general and positive and negative perfectionism in particular.

Concerning the studies conducted on general perfectionism and its possible negative associations, Yildisbas and Topuz (2014) discovered that the overall perfectionism effect was significantly different according to major residence area and GPA (Grade Point Average). Males were more concerned over their mistakes and parental criticism whereas females were more involved in organization. Moreover, the English Language students were more concerned about personal standards than the Psychological Counseling counterparts.

Siegle and Schuler (2000) found out that males were more perfectionist than females. While the Psychological Counseling students were more concerned over their mistakes and doubts about actions, the EFL counterparts were more concerned about their mistakes and personal standards.

Blankstein and Dunkley (2002) found an association between socially prescribed perfectionism and maladaptive motivation, since the fear of failure motivates the socially prescribed perfectionists to gain academic achievement. On the other hand, Ebrahimi, Delavar, Ahadi, and Jomehri (2011) noticed that negative perfectionism was correlated with irrational beliefs and self-esteem.

The investigation by Kiani and Khodabakhsh (2014) revealed a relationship between perfectionism, stressful life events, and depression in high school girls. Likewise, in another study, Roohafza, Afshar, Sadeghi, Soleymani, Saadaty, Matinpour, and Asadollahi (2010) found an association between negative perfectionism and depression on one hand and a negative relationship with academic achievement, which had a converse relationship with positive perfectionism.

The results of the study by Pishghadam and Akhondpoor (2011) indicated that the perfectionist tendencies in foreign language learners were accompanied with low academic achievement, anxiety, and poor reading, speaking, and listening performances. Besides, it was revealed that in the educational context of Iran, the ideas of the "best", the "perfect", and "flawlessness" are valued in many levels including foreign language proficiency. 
Rastegar and Karami (2015) observed a relationship between language learning aptitude and language achievement and belief about the difficulty of language learning and concern over mistakes. Likewise, Ghorban Dordinejad and Moradian Ahmadabad (2014) noticed that maladaptive perfectionists demonstrated lower EFL scores and more anxiety than their adaptive and non-perfectionist counterparts. Besides, a relationship between perfectionism and foreign language anxiety was found.

Concerning the studies conducted on the general perfectionism or its positive aspects, Seyyedi and Afghari (2011) found out that there is no relationship between learners' perfectionism and their language proficiency level concerning their gender and level. Besides, a relationship was revealed between Iranian EFL teachers' perfectionism and their students' language proficiency. Moreover, Shokrollahi and Baradaran's (2014) investigation revealed an association between Iranian EFL teachers' perfectionism and their reflectivity.

The results of the study conducted by Fahim and Noormohammadi (2014) revealed that positive perfectionism was more predictive of students' use of language learning strategies. High achievers were more positive perfectionists while low achievers revealed both positive and negative perfectionism.

Still some very few studies like the current one have been conducted on the investigation of both positive and negative aspects of perfectionism simultaneously. Accordingly, the results of the study conducted by Ram (2005) revealed that positive perfectionism was accompanied with higher academic achievement, higher achievement motivation, general well-being, and more use of coping strategies, while negative perfectionism was associated with negative affect, depression, anxiety, stress, and more use of dysfunctional coping strategies. On the other hand, the investigation by Kanten and Yesiltas (2015) revealed the negative effects of negative perfectionism on psychological well-being and the positive effects of positive perfectionism on work engagement and psychological state.

Andrews, Burns, and Dueling's study (2014) resulted in an association between positive perfectionism with optimism and consciousness while negative perfectionism was correlated with pessimism and neuroticism. On the other hand, Soliemanifar, Rezaei, Rasuli, and Rasuli (2015) found a negative association of positive perfectionism with depression and academic rumination while negative perfectionism was associated with depression and academic rumination.

As it may be evident, though the recent studies have mainly focused on the multidimensionality of the perfectionism construct; they have not yet adequately distinguished between the distinct negative and positive aspects of this concept. Moreover, the positive aspects of this construct have been mainly ignored for years.

Still another significance pertains to the fact that since negative aspects of perfectionism may have devastating consequences on one's psychological state, distinguishing between the adaptive and maladaptive dimensions of perfectionism has important implications for students' social and academic progress. In addition, this recognition may remove the socially recognized 
conception that perfectionism in general may not be devastating while its positive aspects may lead to significant social and academic achievements.

Another gap stems from the fact that no investigation has been yet conducted as to compare the general perfectionism and its negative and positive aspects of EFL and non-EFL major students to see whether the variable of major in general or the act of EFL learning has any positive or negative influence on the perfectionism of EFL major vs. non-EFL major students. The possible effect of these variables on the perfectionism of EFL major and non-EFL major students was implicated through the results of the study by Yildisbas and Topuz (2014).

Still not less importantly, the general perfectionism of English major graduate students worldwide and the negative and positive perfectionism of EFL students and more specifically, the Iranian ones have not yet been investigated, to the researchers' best knowledge. This gap seems to be significant since during the university education period, it is of crucial importance that the students' perfectionism level and its determinants be recognized in order to show how perfectionism and its dimensions affect the educational processes of students (Kanten \& Yesiltas, 2015). This issue is further complicated when no study has investigated the perfectionism of EFL vs. non-EFL major graduate students in general since the EFL students may more suffer from the negative aspects of perfectionism due to the possible negative concurrent effects of EFL learning such as stress, anxiety, apprehension, and nervousness (Hashemi, 2011). This seems so while it is of crucial importance for such students to improve the positive aspects of perfectionism and eradicate its negative aspects when their prospective role as teachers is taken into consideration.

Furthermore, it is of significant importance for students to be aware of the roots of their perfectionism for their current or subsequent professional and personal development. It contributes to their understanding of how perfectionism may affect their life circumstances and may help them to manage such aspects for their academic success and life happiness.

Another significance pertains to the fact that the studies on perfectionism need to address different levels of life which may possibly include post-graduate studies. This provides a lifelong developmental scheme of perfectionist attribute which may contribute to the clear illustration of this phenomenon and its possible influences on different life stages (Kanten \& Yesiltas, 2015).

In order to fill these gaps, there was an attempt to address the negative and positive perfectionism of EFL and non-EFL graduate students in the Iranian context by answering the following research questions and formulating the relevant null hypotheses.

1. Is there any significant difference between the positive perfectionism of EFL and non-EFL graduate students? Which group benefits more from the positive perfectionism? Why?

2. Is there any significant difference between the negative perfectionism of EFL and non-EFL graduate students? Which group suffers more from the negative perfectionism? Why? 


\section{Method}

\section{Participants}

A total number of 73 participants including two groups of graduate students, one of which was Master of Arts (M.A.) graduate students of TEFL $(n=47)$ and the other one was M.A. graduate students of History and Philosophy of Education $(n=26)$ from two Iranian state universities, participated in the current study. On the whole, majority of the participants were females $(n=$ $69 ; 94.5 \%)$ and the remaining $(n=4 ; 5.5 \%)$ were males. Most of the graduate students who participated in the study were between the age ranges of 22-51 years old (Mean age range $=32$ $41, S D=1.79$ ). All of the TEFL students had EFL learning experiences (i.e., from five years to twenty years) while most the students of History and Philosophy of Education had no experience of EFL learning besides their academic and school educations (i.e., except two students with four and one with three years, just a few with less than one year).

The convenience non-random sampling was used for the participants' selection of the current study. Accordingly, all of the graduate students of the History and Philosophy of Education, who were available in one but not the other selected state university, were asked to participate in the current study. The reason behind the selection of the students of History and Philosophy of Education besides those of TEFL was that both majors commonly are related to education principles and teaching methods and methodologies. On the other hand, those students of History and Philosophy of Education are required to pass courses related to the Islamic principles of education, which might have had an implicit positive influence on the positive perfectionism of the mentioned graduate students. On the other hand, it should be considered that the TEFL major students have been interacting with another language which might have some influence in corroborating perfectionist tendencies and associated negative aspects (Yildisbas \& Topuz, 2014). Table 1 offers an overview of the distribution of the participants of this investigation.

Table 1. A Profile of the Participants

\begin{tabular}{lccccc}
\hline \multirow{2}{*}{ University } & \multicolumn{2}{c}{ Graduate students of TEFL } & $\begin{array}{c}\text { Graduate students of History and } \\
\text { Philosophy of Education }\end{array}$ & Total \\
\cline { 2 - 6 } & Male & Female & Male & Female \\
University 1 & - & 21 & - & 26 & 47 \\
University 2 & 4 & 22 & - & - & 26 \\
Total & 4 & 43 & - & 26 & 73 \\
\hline
\end{tabular}

\section{Instrument}

For the purpose of data collection, the 40-item PANPS developed by Terry-Short et al. (1995) was utilized. It included 20 Likert-scale items on positive and 20 items on negative 
perfectionism, for which the participants were required to select items based on a 5-point Likert Scale from 1. (Strongly disagree) to 5. (Strongly agree).

The results of the Cronbach alpha coefficient analysis reported acceptable internal consistency of .79 and .73 values for positive and negative perfectionism, respectively. Considering Hill's (2016) statement that the overall reliability of the original questionnaire is more than .70, the reliability for the two parts of the present scale seems satisfactory.

\section{Procedure}

Data for the present study were collected throughout the spring semester of the academic year 2015-2016. First, the full consent of the instructors and students, whose classes were selected for questionnaire administrations, was gained beforehand and they were informed of the purpose of the study which was not to evaluate their teaching and learning respectively but to gain some fruitful insights regarding the graduate students' negative and positive perfectionism. Then, the data collection was administered by the researcher at the first or the last 20 minutes of the corresponding classes. Before the students complete the questionnaires, they were informed of the purpose of the study, confidentiality of the gathered data, and the required instructions. During their questionnaire completions, they felt free to ask the researcher any questions they might have.

The English version of the PANPS (Terry-Short et al., 1995) was used for the TEFL students while the Persian version (Besharat, 2003), which was available online at www.questionnaire1.com, was administered to the students of History and Philosophy of Education since they did not have a sound English competence.

\section{Results}

The obtained data were transformed into the Statistical Package for Social Science (SPSS version 17) and was analyzed consequently by using descriptive statistics followed by the Independent-samples t-tests to see whether there is any significant difference between the positive and negative perfectionism of the above-mentioned groups.

In order to facilitate interpretation of the questionnaire findings, the items that measured the positive perfectionism (i.e., 2, 3, 9, 6, 14, 16, 18, 19, 21, 23, 24, 25, 28, 29, 30, 32, 34, 35, 37, $\& 40)$ were categorized into the total positive perfectionism score. On the other hand, the negative perfectionism category included the remaining 20 items (i.e., 1, 4, 7, 8, 10, 11, 12, 13, $15,17,20,22,26,27,31,33,36,38, \& 39)$.

Table 2 displays the descriptive statistics of the positive perfectionism of the TEFL and History and Philosophy of Education students. As the mean difference of the total positive perfectionism of the graduate students illustrates, the TEFL students seemed to have a higher positive perfectionism score $(M=81.05)$ rather than the other non-EFL group $(M=78.91)$. 
Table 2. The Descriptive Statistics of the Positive Perfectionism of the TEFL and History and Philosophy of Education Students

\begin{tabular}{cccccc}
\hline & Major & Number & Mean & $\begin{array}{c}\text { Standard } \\
\text { deviation }\end{array}$ & $\begin{array}{c}\text { Standard error } \\
\text { mean }\end{array}$ \\
\cline { 2 - 5 } Score & $\begin{array}{c}\text { Islamic } \\
\text { philosophy } \\
\text { TEFL }\end{array}$ & 23 & 78.91 & 7.931 & 1.654 \\
& 39 & 81.05 & 8.660 & 1.387 \\
\hline
\end{tabular}

Although there was a slight degree of mean difference, the results of the independent samples ttests on the positive perfectionism of the EFL and non-EFL group (See Table 3) revealed no significant difference between the positive perfectionism of EFL $(M=81.05, S D=8.660)$ and non-EFL major counterpart group $M=78.91, S D=7.931 ; t(60)=-.968, p=.33$ (two-tailed). The magnitude of the difference in the means (mean difference: $2.14 ; 95 \%$ CI: -6.55 to 2.27 ) was small (eta squared: .01), indicating that both groups seem to benefit from a considerable degree of positive perfectionism.

Table 3. The Independent Samples T-Test for Positive Perfectionism

\begin{tabular}{|c|c|c|c|c|c|c|c|c|c|c|}
\hline & \multicolumn{3}{|c|}{$\begin{array}{c}\text { Levene's test for equality of } \\
\text { variances }\end{array}$} & \multicolumn{7}{|c|}{$\mathrm{T}$-test for equality of means } \\
\hline & & & & & & & & & \multicolumn{2}{|c|}{$\begin{array}{l}95 \% \text { Confidence } \\
\text { interval of the } \\
\text { difference }\end{array}$} \\
\hline & & $F$ & Sig. & $t$ & $d f$ & $\begin{array}{c}\text { Sig. } \\
\text { (2-tailed) }\end{array}$ & $\begin{array}{c}\text { Mean } \\
\text { difference }\end{array}$ & $\begin{array}{l}\text { Standard } \\
\text { error } \\
\text { difference } \\
\end{array}$ & Lower & Upper \\
\hline Score & $\begin{array}{c}\text { Equal } \\
\text { variances } \\
\text { assumed }\end{array}$ & 1.109 & .297 & -.968 & 60 & .337 & -2.138 & 2.208 & -6.556 & 2.279 \\
\hline
\end{tabular}

On the other hand, the descriptive statistics of the negative perfectionism of the TEFL and the History and Philosophy of Education students (See Table 4) revealed that both groups of students do not suffer much from negative perfectionism. However, the latter group gained a higher negative perfectionism mean score (62.10), this difference seems to be trivial in contrast with the former group's mean score (61.58). A comparison of these mean scores with the positive perfectionism mean scores of the above-mentioned groups revealed that both groups benefit more from the positive perfectionism rather than suffer from negative aspects of perfectionism.

Table 4. The Descriptive Statistics of the Negative Perfectionism of the TEFL and History and Philosophy of Education Students

\begin{tabular}{|c|c|c|c|c|c|}
\hline & Major & Number & Mean & $\begin{array}{l}\text { Standard } \\
\text { deviation }\end{array}$ & $\begin{array}{c}\text { Standard error } \\
\text { mean }\end{array}$ \\
\hline \multirow[t]{2}{*}{ Score } & $\begin{array}{c}\text { Islamic } \\
\text { philosophy }\end{array}$ & 21 & 62.10 & 6.268 & 1.368 \\
\hline & TEFL & 40 & 61.58 & 10.188 & 1.611 \\
\hline
\end{tabular}


As table 5 demonstratives, the results of the negative perfectionism Independent Samples t-test revealed that there is no significant difference $(p>.05)$ between the negative perfectionism of the TEFL $(M=61.58, S D=10.18)$ and the History and Philosophy of Education groups $(M=$ $62.10, S D=6.268 ; t(59)=.21, p=.83$ (two-tailed). The magnitude of the difference in the means (mean difference: .52; $95 \%$ CI: -4.36 to 5.40 ) was very small (eta squared: .001), indicating that both groups suffer from a quite slight amount of negative perfectionism to a same extent.

Table 5. The Results of the Negative Perfectionism Independent Samples T-Test

\begin{tabular}{|c|c|c|c|c|c|c|c|c|c|}
\hline \multirow[b]{4}{*}{ Score } & \multicolumn{3}{|c|}{$\begin{array}{l}\text { Levene's test for equality } \\
\text { of variances }\end{array}$} & \multicolumn{6}{|c|}{ T-test for equality of means } \\
\hline & \multirow[b]{2}{*}{$F$} & \multirow[b]{2}{*}{ Sig. } & \multirow[b]{2}{*}{$t$} & \multirow[b]{2}{*}{$d f$} & \multirow[b]{2}{*}{$\begin{array}{c}\text { Sig. } \\
\text { (2-tailed) }\end{array}$} & \multirow[b]{2}{*}{$\begin{array}{c}\text { Mean } \\
\text { difference }\end{array}$} & \multirow[b]{2}{*}{$\begin{array}{l}\text { Std. error } \\
\text { difference }\end{array}$} & \multicolumn{2}{|c|}{$\begin{array}{l}95 \% \text { Confidence } \\
\text { interval of the } \\
\text { difference }\end{array}$} \\
\hline & & & & & & & & Lower & Upper \\
\hline & 5.642 & .021 & .213 & 59 & .832 & .520 & 2.439 & -4.360 & 5.401 \\
\hline
\end{tabular}

\section{Discussion and Conclusion}

As mentioned earlier, the current study aimed at investigating the positive and negative perfectionism of Iranian EFL and non-EFL students in general and investigating whether there is any significant influence of major on the above-mentioned variables.

Concerning the positive perfectionism of the graduate students, the results revealed that there is no significant difference between the positive perfectionism of EFL and non-EFL learners while both groups equally benefit from a high degree of positive perfectionism. This finding, which does not corroborate the possible negative impact of EFL learning on positive perfectionism of the graduate students, reveals that positive perfectionism is not related to the later-developing variables such as major or the act of EFL learning. These results seem in contrast to the results by Siegle and Schuler (2000) in which the EFL students were found to be more concerned with their mistakes and personal standards.

According to the findings of the literature (Ashby, Slaney, \& Mangine, 1996), positive perfectionism may be strengthened during the early childhood bearing practices and the household child-parent interactions through the emphasis on orderliness, organization, personal standards, and positive striving. This impact might be prevailing in the Iranian context through the Iranian child-bearing and educational practices, which excessively strengthen the concepts of the "best", the "perfect", and "flawlessness" at different developmental levels (Pishghadam $\&$ Akhondpoor, 2011). These results lend credence to the fact that the later-coming variables of academic major or EFL learning act have no considerable consequence on the perfectionism of the students.

The indifference between the positive perfectionism of EFL and non-EFL learners was in contrast to the results of Yildisbas and Topuz (2014) in which the nonnative speaking English 
Language graduate students were more concerned with personal standards as an aspect of positive perfectionism rather than their non-EFL counterparts. Furthermore, the beneficence of positive striving as a sub-scale of positive perfectionism was consistent with the findings of the study conducted by Roohafza et al. (2010) and Siegle and Schuler (2000).

More specifically, the slight higher degree of the positive perfectionism of the TEFL graduate students in contrast to their counterpart non-EFL peers from the History and Philosophy of Education major may strengthen the fact that the act of Islamic education, which is more strengthened through the latter major, has no significant influence on the development of positive perfectionism strivings in the graduate students. However, the Islamic education principles may emphasize on the development of the positive aspects of perfectionism in children such as orderliness, organization, and positive striving (Hosseini zadeh, 2012). This discrepancy seems to corroborate the above-mentioned fact that the later-coming variables of the academic major or EFL learning act have no considerable consequence on the perfectionism of the students.

Regarding the negative perfectionism, the results revealed a non-significant difference between the negative perfectionism of the above-mentioned EFL and non-EFL groups. However, the latter group revealed a very slight higher degree of negative perfectionism, both EFL and nonEFL groups equally showed a slight degree of negative perfectionism. While this seems to be minor, it should be eradicated since according to the results of the previous literature (Blankstein \& Dunkley, 2002; Neumeister, 2004), the unintentional implicit consequences of negative perfectionism such as too much concern about social norms, details, orderliness, regulation, selfassessments, other evaluations, fear of failure, performance-avoidance goals, and procrastination might lead to devastating psychological outcomes for one's health and success.

Besides, even this slight degree of negative perfectionism may even complicate the issue when the possible prospective performances of the graduate students in general and those of the current study as future teachers in particular, who may corroborate the unrealistic perfectionist expectations in their students, are considered. However, it should be noted that there is a strong need to lower the affective filters of negative aspects of perfectionism, which may lead to negative consequences of academic burnout, procrastination, low motivation, lack of selfconfidence, high anxiety, and subsequent lower academic success.

On the other hand, positive side effects of perfectionism should not be ignored. In consistent with the results of the literature, there may be possible associations between Iranian EFL teachers' perfectionism and enhancement of their reflectivity (Shokrollahi \& Baradaran, 2014) or their students' language proficiency (Seyyedi \& Afghari, 2011), which may be points for further research with respect to the graduate students as prospective teachers.

Due to inclusion of more females in comparison with males and also some limitations such as the use of convenience sampling and cross-sectional nature of the study, one must be cautious in generalizing the results obtained. These results may differ with the inclusion of some other universities nationwide. In sum, these results may alert one to the beneficence of the 
development of the positive perfectionism strivings in students in general and help them to eradicate their negative perfectionist aspects, if any.

\section{Acknowledgment}

We would like to thank Dr. Azam Sazvar, Dr. Leila Tajik, and Dr. Golnar Mazdayasna from the English Language and Literature departments as well as Dr. Sattari, Dr. Banahan, and Dr. Reza zadeh from the History and Philosophy of Education department, who devoted their precious class time to our research purpose.

\section{Referencias}

Accordino, D. B., Accordino, M. P., \& Slaney, R. B. (2000). An investigation of perfectionism, mental health, achievement, and achievement motivation in adolescents. Psychology in the Schools, 37(6), 535-545.

Alden, L. E., Ryder, A. G., \& Mellings, T. (2002). Perfectionism in the context of social fears: Toward a two-component model. American Psychological Association, 14(435), 375-393.

Andrews, D. M., Burns, L. R., \& Dueling, J. K. (2014). Positive perfectionism: Seeking the healthy "should", or should we? Open Journal of Social Sciences, 2(8), 27-34.

Ashby, J., Slaney, R., \& Mangine, J. (1996, August). An investigation of the relationship between perfectionism and the big-five factor structure. Poster session presented at the annual meeting of the American Psychological Association, Toronto, Canada.

Blackburn, S. M. (2003). The relationship between perfectionism, aversive self-awareness, negative affect, and binge eating. (Unpublished master's thesis). University of Canterbury, Christchurch, Canterbury, New Zealand.

Blankstein, K. R., \& Dunkley, D. M. (2002). Evaluative concerns, self-critical, and personal standards perfectionism: A structural equation modeling strategy. American Psychological Association, 14(435), 285-315.

Blankstein, K. R., \& Winkworth, G. R. (2004). Dimensions of perfectionism and levels of attributions for grades: Relations with dysphoria and academic performance. Journal of Rational-emotive and Cognitive-behavior Therapy, 22(4), 267-295.

Burns, L. R., \& Fedewa, B. A. (2005). Cognitive styles: Links with perfectionist thinking. Personality and Individual Differences, 38(1), 103-113.

Campbell, J. D., \& Paula, A. D. (2002). Perfectionistic self-beliefs: Their relation to personality and goal pursuit. American Psychological Association, 14(435), 181-198.

Chang, E. C. (2008). An examination of optimism, pessimism, and performance perfectionism as predictors of positive psychological functioning in middle-aged adults: Does holding high standards of performance matter beyond generalized outcome expectancies? Cognit Ther Res, 33(3), 334 44. doi: 10.1007/ s10608-008-9215-9.

Chang, E. C., Ivezaj, V., Downey, C. A., Kashima, Y., \& Morady, A. R. (2008). Complexities of measuring perfectionism: Three popular perfectionism measures and their relations with eating disturbances and health behaviors in a female college student sample. Eating Behaviors, 9(1), 102-110. 
Ebrahimi, M. E., Delavar, A., Ahadi, H., \& Jomehri, F. (2011). Representation of a structural model about relationship between perfectionism and attachment styles, irrational beliefs and self-esteem. Education Sciences and Psychology, 2(19), 93-98.

Fahim, M., \& Noormohammadi, R. (2014). An investigation into perfectionism as a moderator of the links between language learning styles and strategies. Journal of Language Teaching and Research, 5(5), 1121-1131.

Flett, G. L. \& Hewitt, P. L. (2002). Perfectionism and maladjustment: An overview of theoretical, definitional, and treatment issues. In G. L. Flett \& P. L. Hewitt, (Eds.), Perfectionism: Theory, research, and treatment (pp. 5-31). Washington, DC: American Psychological Association.

Flett, G. L., Hewitt, P. L., Blankstein, K. R., \& Gray, L. (1998). Psychological distress and the frequency of perfectionist thinking. Journal of Personality and Social Psychology, 75(5), 1363-1381.

Flett, G. L., Hewitt, P. L., Blankstein, K., \& O'Brien, S. (1991). Perfectionism and learned resourcefulness in depression and self-esteem. Personality and Individual Differences, 12(1), 61-68.

Flett, G. L., Hewitt, P. L., Oliver, J. M., \& Macdonald, S. (2002). Perfectionism in children and their parents: A developmental analysis. American Psychological Association, 14(435), 89-131.

Frost, R. O., \& DiBartolo, P. M. (2002). Perfectionism, anxiety, and obsessive-compulsive disorder. In G. L. Flett \& P. L. Hewitt (Eds.), Perfectionism: Theory, research, and treatment (pp. 341-371). Washington, DC, US: American Psychological Association. http://dx.doi.org/10.1037/10458-014

Frost, R. O., Marten, P., Lahart, C., \& Rosenblate, R. (1990). The dimensions of perfectionism. Cognitive Therapy and Research, 14(5), 449-468.

Frost, R. O., Turcotte, T. A., Heimberg, R. G., Mattia, J. I., Holt, C. S., \& Hope, D. A. (1995). Reactions to mistakes among subjects high and low in perfectionistic concern over mistakes. Cognitive Therapy and Research, 19(2), 195-205.

Ghorban Dordinejad, F., \& Moradian Ahmadabad, R. (2014). Examination of the relationship between foreign language classroom anxiety and English achievement among male and female Iranian high school students. International Journal of Language Learning and Applied Linguistics World, 6(4), 446-460.

Hamachek, D. E. (1978). Psychodynamics of normal and neurotic perfectionism. Psychology: A Journal of Human Behavior. 15(1), 27-33.

Hashemi, M. (2011). Language stress and anxiety among the English language learners. Procedia-Social and Behavioral Sciences, 30, 1811-1816.

Hewitt, P. L., \& Flett, G. L. (1991). Perfectionism in the self and social contexts: conceptualization, assessment, and association with psychopathology. Journal of Personality and Social Psychology, 60(3), 456.

Hill, A. (Ed.). (2016). The psychology of perfectionism in sport, dance, and exercise. Routledge: New York.

Hosseini zadeh, S. A. (2012). The educational procedure of Prophet Muhammad and his Ahl-e Beit (the educational perspective with an emphasis on the Islamic principles). Qom: Research Institute of Hawzah and University (RIHU). 
Kanten, P., \& Yesiltas, M. (2015). The effects of positive and negative perfectionism on work engagement, psychological well-being and emotional exhaustion. Procedia Economics and Finance, 23, 1367-1375.

Kiani, F., \& Khodabakhsh, M. R. (2014). Perfectionism and stressful life events as vulnerabilities to depression symptoms in students. International Journal of Pediatrics, 2(4.1), 277-285.

Kobori, O., Yamagata, S., \& Kijima, N. (2005). The relationship of temperament to multidimensional perfectionism trait. Personality and Individual Differences, 38(1), 203-211.

Parker, W. D., \& Adkins, K. K. (1995). Perfectionism and the gifted. Roeper review, 17(3), 173-175.

Pishghadam, R., \& Akhondpoor, F. (2011). Learner perfectionism and its role in foreign language learning success, academic achievement, and learner anxiety. Journal of Language Teaching and Research, 2(2), 432-440.

Ram, A. (2005). The relationship of positive and negative perfectionism to academic achievement, achievement motivation, and well-being in tertiary students. (Unpublished master's thesis). University of Canterbury, Christchurch, Canterbury, New Zealand.

Rastegar, M., \& Karami, M. (2015). On the relationship between foreign language anxiety, willingness to communicate, and scholastic success among Iranian EFL learners. Theory and Practice in Language Studies, 5(11), 2387-2395.

Rice, K. G., Ashby, J. S., \& Slaney, R. B. (1998). Self-esteem as a mediator between perfectionism and depression: A structural equations analysis. Journal of counseling psychology, 45(3), 304-314.

Roohafza, H., Afshar, H., Sadeghi, M., Soleymani, B., Saadaty, A., Matinpour, M., \& Asadollahi, G. (2010). The relationship between perfectionism and academic achievement, depression, and anxiety. Iranian Journal of psychiatry and behavioral sciences, 4(2), 31-36.

Seyyedi, T. S. (2011). The relationship between Iranian EFL teachers and learners perfectionism and language proficiency. (Doctoral dissertation). Sheikhbahaee University, Isfahan, Iran.

Shokrollahi, M., \& Baradaran, A. (2014). On the relationship between Iranian EFL teachers perfectionism and their reflectivity. International Journal of Language Learning and Applied Linguistics World, 7(3), 13-28.

Siegle, D., \& Schuler, P. A. (2000). Perfectionism differences in gifted middle school students. Roeper Review, 23(1), 39-44.

Silverman, L. K., \& Conarton, S. A. (2005). Gifted development: It's not easy being green. In D. Comstock (Ed.), Diversity and development: Critical contexts that shape our lives and relationships (pp. 233-251). Pacific Grove, CA: Wadswoth, Brooks Cole.

Slaney, R. B., Rice, K. G., \& Ashby, J. S. (2002). A programmatic approach to measuring perfectionism: The almost perfect scales. In G. L. Flett \& R. Hewitt (Eds.), Perfectionism (pp.63-88). Washington, D. C: American Psychological Association.

Soliemanifar, O., Rezaei, Z., Rasuli, A. A., \& Rasuli, M. (2015). The Relationship between Positive and Negative Perfectionism and Depressive Symptoms: The Role of Academic Rumination. Jentashapir Journal of Health Research, 6(6). 21-26. doi: 10.17795/jjhr28709 
Stöber, J. (1998). The Frost Multidimensional Perfectionism Scale revisited: More perfect with four (instead of six) dimensions. Personality and Individual Differences, 24(4), 481-491.

Stumpf, H., \& Parker, W. D. (2000). A hierarchical structural analysis of perfectionism and its relation to other personality characteristics. Personality and Individual Differences, 28(5), 837-852.

Suddarth, B.H. \& Slaney, R.B. (2001). An investigation of the dimensions of perfectionism in college students. Measurement and Evaluation in Counseling and Development, 34(3), 157-165.

Terry-Short, L. A., Owens, R. G., Slade, P. D., \& Dewey, M. E. (1995). Positive and negative perfectionism. Personality and individual differences, 18(5), 663-668.

Terry-Short, L. A., Owens, R. G., Slade, P. D., \& Dewey, M. E. (1995). Positive and Negative Perfectionism Scale [Measurement instrument]. Retrieved from (Owens, R. G., personal communication, March 3, 2016).

Terry-Short, L. A., Owens, R. G., Slade, P. D., \& Dewey, M. E. (1995). Positive and Negative Perfectionism Scale [Porseshname-ye kamal geraei mosbata va manfi-ye Terry-Short va Hamkaran (M. A. Besharat, Trans.)] [Measurement instrument]. Retrieved from http://questionnaire1.com/.

Yildizbas, F., \& Topuz, C. (2014). The Study of Teacher Candidates Perfectionism in Relation with Achievement and Demographics. Procedia-Social and Behavioral Sciences, 152, 121-126. https://doi.org/10.1016/j.sbspro.2014.09.167 